\title{
11 The Activist Chroniclers of Occupy Gezi: Counterposing Visibility to Injustice
}

\author{
Dan Mercea and Helton Levy
}

\begin{abstract}
With the benefit of hindsight, this chapter casts another glance at Occupy Gezi, a landmark protest in contemporary Turkey. We reflect on the pursuit of visibility by activists on Twitter as a means to garner the attention of the Turkish and the global public to the heavy-handed police crackdown of the popular mobilization. We interpret their quest for visibility as a 'subaltern tactic' employed to reverse an asymmetry of power through an aesthetics of indignation at the injustice perpetrated against peaceful demonstrators. In the longer run, however, such visibility poses an important dilemma when, as in the case of Turkey, it becomes the basis for reflexive state surveillance.
\end{abstract}

Keywords: Occupy Gezi, Twitter, visibility, injustice frame, recognition, participation

\section{Introduction}

In 2013, Occupy Gezi became a milestone in contemporary Turkish history and politics. The protest was an expression of participatory democracy understood as a desire for more immediate and efficacious collective input in democratic governance (Della Porta 2013a). At the same time, it was an outcry against the erosion of Turkish democracy. Its institutions, including the mainstream media (Karatas and Saka 2017) commanded decreasing levels of trust (KONDA 2014) while being increasingly hollowed out by a mix of neoliberal policies and the authoritarian tendencies of the Erdoğan government (Iğsız 2014).

McGarry, A., I. Erhart, H. Eslen-Ziya, O.Jenzen, U. Korkut (eds), The Aesthetics of Global Protest: Visual Culture and Communication. Amsterdam: Amsterdam University Press, 2020 DOI 10.5117/9789463724913_CH11 
The reflections that follow focus on the period between late May and late June 2013. In the final days of May, protestors embarked on a quest for visibility on Twitter to garner the attention of the Turkish and the global public to the heavy-handed police crackdown of peaceful demonstrations by environmental activists (Budak and Watts 2015). The protests followed a procedural court challenge to government plans to erect the 'Taksim Military Barracks', a building complex that included shopping and residential units alongside military facilities (Demirhan 2014). The plans would have seen the de facto privatization of Gezi (Iğsız 2014: 28), a metropolitan park that would sit at the heart of the redevelopment site. They evolved into a struggle for recognition and participation: a recognition of the stake that urban residents have in the democratic governance of the environment they inhabit, which they can seek to assert through the courts, within the bounds of the rule of law. Recognition was further sought for the democratic right to participate in a non-violent revolt against the expanding authoritarianism of the then Prime Minister Erdoğan's government, which was subjugating the country's judicial, political and media institutions (Iğsız 2014).

Over the course of two weeks of rolling protests, tweeting compensated for the anaemic coverage of the Gezi occupation by Turkish media. Twitter was used strategically to draw in the global media and help choreograph collective action (Mercea et al. 2018). The visibility thus attained publicized the pursuit of procedural, environmental and social justice (Schlosberg 2007) by the swelling number of politically, socio-economically and culturally diverse protestors (see Vatikiotis and Yörük 2016). The jarring aesthetics of police violence perpetrated against activists was channelled through an injustice frame so as to emphasize the democratic character, means and goals of the protests.

In what follows, we argue that this quest for visibility is an example of a 'subaltern tactic' (Certeau 1984) to reverse an asymmetry of power using an injustice frame. In the short run, this tactic can serve that very goal by subjecting governments to extraordinary levels of global, public scrutiny. In the longer run, however, it poses an important dilemma as it can become a basis for reflexive state surveillance. On the one hand, for the diverse assembly of protestors in Gezi Park, the official government response to the mobilization was portrayed as state repression by dint of a rallying injustice frame. Following the eviction of the encampment, Twitter was used to memorialize 'the Gezi spirit' so as to preserve and continue to make visible the democratic ethos and values of the movement and its legacy (Mercea et al. 2018). On the other hand, this act of resistance prompted a reflexive turn in state surveillance. In 2014, legislation was passed tightening the Turkish 
government's control of the Internet at the same time as rampant state monitoring of social media was aimed at silencing dissident voices (Karatas and Saka 2017:387). Despite rejoicing in a newly found solidarity during the occupation, participants that memorialized the protests by continuing to post about them on Twitter, struggled to preserve its legacy in the volatile political climate of the country since 2013 (Mercea et al. 2018). Below, we first discuss injustice frames and their use by activists around the world to raise the visibility of aggrieved groups.

\section{A Path to Visibility}

We derive the term 'injustice frame' from the tradition of frame analysis in social movements (for an overview, see Benford and Snow 2000). Snow et al. (1986: 466) built on Goffman's (1974: 21) notion of the frame, defined as 'schemata of interpretation' whereby one can make sense of the world around them to characterize an injustice frame as 'a mode of interpretation that defines the actions of an authority system as unjust and simultaneously legitimates noncompliance'. Thus, at a cognitive level, an injustice frame identifies both an issue as inherently egregious and its source as a known actor (Fisher 1997). Frames are thus a heuristic, distilled information, that are used by activists to expediently direct the actions of individuals or groups (Snow et al. 1986).

Young (in Schmitter 2011: 402-403) posited a set of ways in which activists shine a light on the shortcomings of 'real-existing' democracy (RED), its entrenched institutions, and the increasingly organized forms of (special) interest representation that crowd out the public domain of democratic politics. Activists have clamoured for a narrowing of the number of 'characters' involved in REDs (e.g. resource-rich lobby groups or vast transnational corporations that wield a disproportionate influence over elected representatives), that is, the 'exclusivity' of institutionalized deliberative procedures and the fundamental incompleteness of what one calls 'inclusion' in democracy. To them, activists counterpose visibility as a means to achieve recognition for minority or marginalized groups. In this view, visibility for activists is tantamount to securing a place in the public domain that can serve many purposes, from rallying supporters to subverting hegemonic discourses that suppress subaltern contestations of entrenched power relations (Doerr et al. 2013). Protests are a performative enactment of visibility that serves to contest power asymmetries through counterclaims on public space (see Hayward and Komarova, this volume) - both physical, of the street or the 
square and symbolic, as oppositional discourse expressed through placards, pamphlets, fliers or memes.

In past episodes of collective action, the aesthetics of openness, i.e. the way in which protests are performed as public events, has allowed for the bridging - not least through media coverage - of frames instigated by various aggrieved participant groups (Benford 1993). In 2011, the General Assembly at Occupy Wall Street was the embodiment of deliberations that thrashed out shared interpretations of movement grievances and aims, both of which stemmed from an evaluation of public spending cuts as socially unjust (Rehmann 2013). Injustice frames, notably, 'We are the 99\%', aided in the distillation of grievances into discursive tropes and an accessible numerical aesthetics of inequality. Such frames have further drawn on the aesthetics of indignation that was recognized and enacted through worldwide occupations of public space and was carried by the media into a broader public arena (Juris 2012). Aesthetics, in this interpretation, refers to the 'expression or performance of protest' (McGarry et al., this volume).

In the case of Occupy Gezi, an injustice frame emerged representing the coalescence of environmental, social and political grievances. They ranged 'from environmental destruction to the aggressive gentrification of urban spaces, from economic hardship to Turkey's aggressive involvement in the Syrian civil war, from the media and social media censorship to the blocked peace process with the Kurdish liberation movement' (Vatikiotis and Yörük 2016: 9). Everyday experiences shared among protestors can paint such grievances in familiar colours, turning them into appeals to social and political change (a process that Snow et al. [1986: 477] describe as 'frame resonance').

The violent police crackdown at the outset of the Gezi demonstrations on 31 May epitomized the injustice condoned or enforced by the institutions of the state. It acted as a touchpaper setting off large rallies and the occupation of Gezi Park. The aesthetics of police brutality captured with the iconic picture of the 'Woman in Red', a female protestor turned sideways while being pepper-sprayed by a male riot police officer, resonated with a subjective sense of indignation and urgency to respond to the violent hegemony of the state (Farro and Demirhisar 2014). Similarly, Black Lives Matter more recently seized on the conventional imagery of urban safety, the police car, to display the rebellion of those institutionally deemed as suspect, as depicted in a Kendrik Lamar video:

The cop car on stage was demolished as if bombed out, and he, powerfully and defiantly, stood on top of it performing the song that Black Lives 
Matter protestors would draw on weeks later, [...] a contemporary symbol of state oppression that had been re-appropriated as a sign of defiance and empowerment, first by a musician, then by grassroots organizers and protestors who refused to be intimidated. (Lebron 2017:36)

The distillation of daily experience and highly evocative symbols can engender the resonance that propels movements like Black Lives Matter into cultural phenomena that are afforded greater visibility. In its turn, Gezi Park moved from a local, urban planning issue to political resistance against the injustice of unwarranted police violence and a creep towards authoritarianism. This change of scale was overtly aesthetic. Occupy Gezi protestors used the Coca-Cola font to write anti-capitalist slogans (Emre et al. 2014), objecting to the neoliberal privatization of space; they exhibited a 'politics of the body' where 'any body who was discontented or outraged by police violence or felt choked by the authoritarian regime was out in the streets' (Gambetti 2014), and appealed to humour to attract attention to the demonstrations (Balaban 2015; Dagtas 2016).

On social media, the aesthetics of indignation served to reproduce the atmosphere of the occupation at Gezi, broadly framed as an 'injustice' perpetrated against peaceful demonstrators. On Twitter, the swell of information shared during Occupy Gezi made the movement visible both to its supporters, through the circulation of information pertaining to the movement's coordination or participant turnout, and to the media, through the accounting of police violence (Ogan and Varol 2017; Jost et al. 2018). In this chapter, we review Twitter user perceptions of Occupy Gezi and discuss attempts by Gezi protestors to achieve media visibility through this social network.

\section{Visibility Denied and Regained}

In our research, we used Twitter's streaming application programming interface to monitor four Occupy Gezi hashtags (\#direngeziparki, \#occupygezi, \#occupytaksim, \#occupyturkey, see Mercea et al. 2018). Following a close inspection of the tweets covering a period of a month at the height of the protests, in May-June 2013 (see figure 11.1), we contacted 100 users and successfully recruited 24 of them for in-depth interviews.

A small minority of less than 1 per cent of the users in our dataset had tweeted with the Gezi hashtags for at least ten days. The interviewees tweeted for at least 20 days during those two months in 2013 (fig. 11.1). This 


\section{Tweet Timeline}

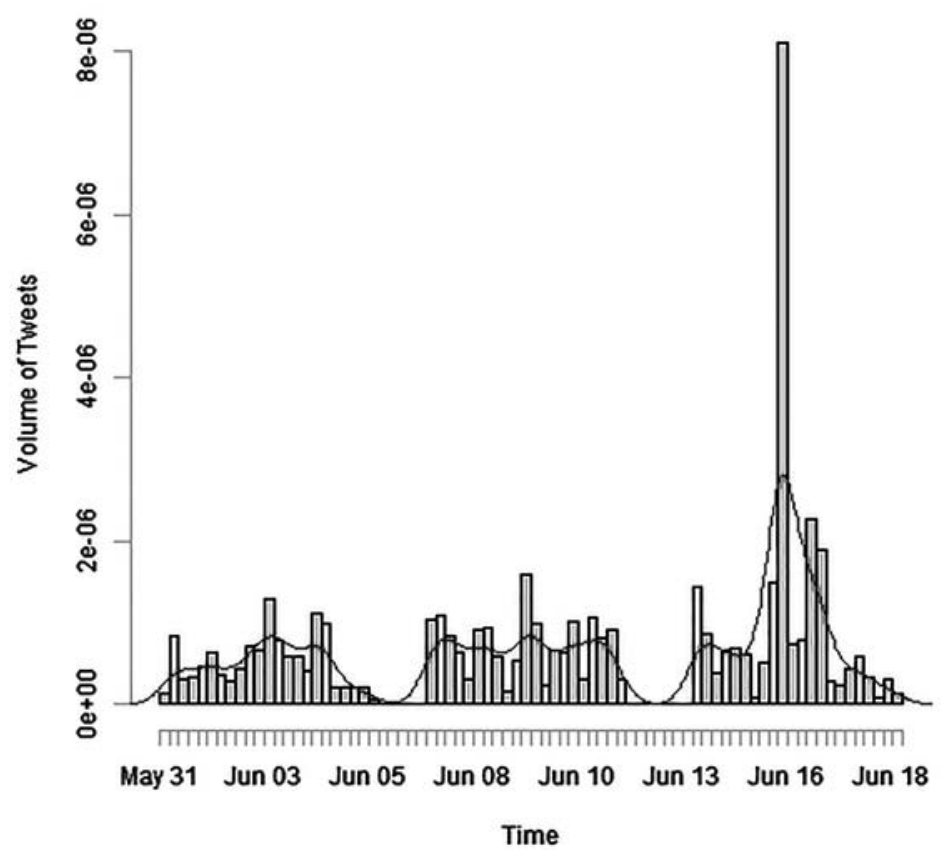

Figure 11.1. The time distribution of Occupy Gezi tweets for May-June 2013.

was a substantial investment of time into the protests whose implications we discussed, in the first instance, in light of the literature on activist persistence.

We showed that tweeting in the service of the Gezi Occupation was a moral act motivated by a desire to convey to a potentially global public the participatory, democratic values that the protests embodied, which were counterposed to the injustices perpetrated by the state (Mercea et al. 2018). This emphasis on values resonated over time. Its openness reminded us of the Global Justice Movement which, in its day, was depicted as 'a movement centred more around values than ideologies [articulated not] [...] through references to big theoretical constructions, but rather by recalling the founding values of justice and peace, dignity and democracy' (Della Porta 2013b: 141).

Occupy Gezi was an experiment in visibility. For our interviewees, all but three of whom were in Turkey and attended the protests, Occupy Gezi represented a temporary suspension of group differences that were recognized through inclusive, participatory decision-making within the governing forum of the occupation. The encampment thus personified a 
'sectional utopia' (Mannheim 1952), predicated on the ideals of the occupiers and the self-governing processes they instituted collectively. Rather than to negate a noted polarization among social groups (KONDA 2014), Occupy Gezi made visible efforts to crystallize and enact a political vision of participatory democracy. That vision was in part a response to the political and later physical violence of the government and state institutions under its control. Once organized, popular opposition to the attempt to force through the privatization of public space was physically repressed for being both an ideological threat and a material obstacle. ${ }^{1}$ As IP 5 (interview by author, 2015, in Mercea et al. 2018) explained,

[Occupy Gezi] was a struggle for justice. [We] were seeking our rights. [...] We emphasized the intervention by Ankara in [the planned redevelopment of] a park in Istanbul. We [had to] pull the government [back down] to the democratic ground again.

The stand-off with the authorities that unfolded over the course of the occupation conspicuously received scant attention from the national broadcasting media. Infamously, CNN Turk screened a penguin documentary as demonstrators clashed with the police on 31 May (Tufekci 2014). In the eyes of our interviewees, this was a glaring dereliction of duty for a pivotal democratic institution and a jarring realization that protestors and their supporters were able to tactically overcome by turning social media and particularly Twitter into an open and public channel for alternative coverage of the protests. In that way, the movement found itself in a position where it was able to generate and propagate its own frames. It thus escaped the definitional power of the media, which had for long decided a 'movement's fate' (Gitlin 2003: 3).

Twitter substituted the mass media but in turn imposed its own constraints on visibility accruing from its socio-technical affordances, its attention economy (Lovink 2011) and its regime of accelerated time (Kaun 2015). One interviewee evocatively described her experience with embracing Twitter to communicate about Gezi:

I have been using Twitter since 2009. I was already using it before Gezi, but I saw it as a platform like Facebook. After that, in 2011-2012, as Twitter use increased, the accounts I have been following turned [...] maybe

1 At least 26 Gezi protesters faced criminal charges, 8 people died and 8,ooo were injured (Letsch 2015). 
a little more political and activist. [...] [At] the beginning of Gezi, the people who got the news first were Twitter users mostly and it was on Facebook a day after. [...] I followed the Gezi process mostly on Twitter, I used Twitter. From the first night when the trees were cut down. [...] I spent the whole protest with an iPad on my lap. For us, the people on the streets, it was important to see what is happening and where because you couldn't reach anybody, anytime. So, we shared that we had many injured people and animals. I experienced this personally. Honestly, we went to some places to save the people who were stuck somewhere, or [...] like when we saw someone's tweet and we brought medicine for people who were having an asthma attack. (IP18, interview by author, 2015, quoted in Mercea et al. 2018)

It is important to understand that Twitter was a contested arena both during the protests and in their aftermath, especially as opponents of the protestors attempted to characterize the social media uprising as foreign interference. This and other conspiracy theories attempted to discredit them also by using flawed official statistics of event attendance (Özel 2014). An important reason why Twitter was and remained contested was because of the visibility within Turkish society that the protestors gained through it for their collective effort. The visibility pursued by the protestors was multipronged and served multiple purposes. On the one hand, interviewees recounted aiming to sensitize peers - family, friends, acquaintances - to the protests, their civic-ness and extraordinary nature as an enactment of participatory democracy. As one interviewee recalled:

I started to tweet as a reaction to the destruction of this green area. It was a social reaction. [...] It was a civic and social concern. [...] It was a desire and need to make things visible. It was a prompt response to share my concerns and worries. I wanted to share my worries and sensitivity. ( $\mathrm{IP}_{3}$, interview by author, 2015, in Mercea et al. 2018, emphasis added)

At the same time, visibility was a sought upshot of an already documented course of action (Olesen 2017:658) of chronicling the injustice of the asymmetrical symbolic violence perpetrated by the government and the media. They suppressed coverage so as to preserve the dominant discourse on the scope, significance and legitimacy of the protests (cf. Bourdieu 1999). Tweeting to attain visibility became a media practice whereby activists could wrest some control over the coverage of their outcry (Mattoni and Treré 2014), turning it into an eventful political protest with a potential 
to engender further social change (Della Porta 2008), by laying bare the physical aggression against them meted out by state institutions. Faced with the realization that '[the] authorit[ies] controlled the central media hubs', activists courted the attention of the international media, thereby loosening the grip of national institutions on the flow of information. IP9 argued that 'Twitter challenged the control of the media hubs' while IP4, $\mathrm{IP}_{5}$, and IP12 said:

The repression and dominance of the existing political organization over the public made people explode. And I exploded like [other] individuals in society. We used Twitter to get news and be aware of what is going on through the accounts that we know, and we trust. Twitter became an information tool for us, not a target. (IP4, interview by author, 2015, in Mercea et al. 2018)

The media [were reduced to a] Penguin [documentary]. We were all walking media. I tweeted in English, to the media in US, Russia, Italy. I tweeted directly mentioning the presidents, the prime ministers. I gained many followers Italian, German from different nations. (IP5, interview by author, 2015, in Mercea et al. 2018)

I tweeted about 27 May. [...] [C]elebrities retweeted and tweeted about [it]. [...] [B]ulldozers stopped and went away. Even though the media were there and recorded the events, there was no coverage of the event in the media. On 31 May [...] there were hundreds of thousands of people [in Taksim Square] and there was police violence on the streets. But there was nothing in the media. Then I prepared eight tweet templates on what was going on in Turkey and how the case developed and sent them to Twitter celebrities mentioning the international trustable news [outlets] like the New York Times, CNN, BBC, The Guardian, etc. [...] at the end of the tweets. It must have been 1 June. [The tweet to CNN alone got] more than 8,400 retweets. Then, later [that day] CNN International started to broadcast live from Taksim. (IP12, interview by author, 2015, in Mercea et al. 2018)

As IP12 clarifies, visibility allowed participants and potential participants to form a realistic impression of 'what is going on' onsite while providing remote media observers with stories ready for their news feeds and ticker tapes. The latter work was carried out strategically by protestors to ensure that international media are 'up to date' with events on the ground (Baruh and Watson 2015; Mercea et al. 2018). Importantly, also, Occupy Gezi received 
much support from the Turkish diaspora. The group tweeted extensively and helped the protest attain international visibility, albeit from the safety of their remote locations (Ogan et al. 2016).

This composite 'coverage' that surpasses the dichotomy between a hegemonic media narrative and an alternative activist one (see Levy 2018), ended up allowing the Gezi activists to narrate the events themselves with the best support they could get from within the movement. In the words of one activist:

Since the intervention was inhumane, I decided to use my talents and expertise which are on social media and organizational capabilities to support the protestors in the field. I helped the protestors through creating organizational opportunities, like mapping, providing coordination between people and monitoring CCTV. (IP13, interview by author, 2015, in Mercea et al. 2018)

\section{Conclusion}

In the short term, the Gezi activists were able to circumvent the obstacles to visibility for the Gezi movement. A scrambled protest event in a public square became an 'eventful' (Della Porta 2008) occupation that transformed a localized call for environmental justice into a wider appeal for recognition and participation. Its quest for visibility - made vivid through the images broadcasted via social media - was instrumental to this process. As Hayward and Komanova's (this volume) case study of the Orange parade in North Belfast cogently evinced, the visibility of a contentious event such as Occupy Gezi likewise opens up a space of solidarity, and resistance or challenge to authority. In turn, new political opportunities and threats (Tarrow 2011) can arise from the heightened visibility - in the form of new allies and adherents or, on the other hand, state repression and surveillance.

In the long term, the vivid aesthetics of the Gezi protest may survive attempts to efface it from public discourse. In 2018 Turkey, important sites for these events have seen abandonment and depredation when repurposed for showcasing the political right (Evered 2018; Zik 2018). While Twitter contributed to the attainment of visibility, a key outcome pursued by the protestors in Gezi Park and the nearby iconic Taksim Square, social media equally demonstrated their limitations. These were evident particularly in respect to access and continuity of service in the hands of activists (Tufekci 2017) rising in opposition to the erosion of democracy, freedom of assembly, 
freedom of speech and the rule of law, ongoing repression and surveillance. What is left in the wake of Gezi is the immaterial frame of a collective sense of 'injustice' whose erstwhile prominent place in public discourse has created a memory and political culture that, although fiercely tested following the 2016 attempted coup against president Erdoğan, endures.

\section{References}

Balaban, Utku. 2015. 'Vernacular Utopias: Mimetic Performances as Humour in Gezi Park and on Bayındır Street', in Creativity and Humour in Occupy Movements: Intellectual Disobedience in Turkey and Beyond, ed. A. Yalcintas, 48-74 Basingstoke: Palgrave.

Baruh, Lemi, and Hayley Watson. 2015. 'Social Media Use during Political Crises', in The Routledge Companion to Social Media and Politics, ed. Axel Bruns, Gunn Enli, Eli Skogerbø, Anders Olof Larsson, and Christian Christensen, 198-211. Abingdon: Routledge.

Benford, Robert D. 1993. "You Could Be the Hundredth Monkey": Collective Action Frames and Vocabularies of Motive within the Nuclear Disarmament Movement', Sociological Quarterly 34: 195-216.

Benford, Robert D., and David Snow. 2000. 'Framing Processes and Social Movements: An Overview and Assessment', Annual Review of Sociology 26: 611-639.

Bourdieu, Pierre. 1999. Language and Symbolic Power. Cambridge, MA: Harvard University Press.

Budak, Ceren, and Duncan J. Watts. 2015. 'Dissecting the Spirit of Gezi: Influence vs. Selection in the Occupy Gezi Movement', Sociological Science 2: 370-397.

Certeau, Michel de. 1984. The Practice of Everyday Life. Berkeley: University of California Press.

Dagtas, Mahiye Secil. 2016. 'Down With Some Things! The Politics of Humour and Humour as Politics in Turkey's Cezi Protests', Etnofoor 28(1): 11-34.

Della Porta, Donatella. 2008. 'Eventful Protests, Global Conflicts', Distinktion 17: 27-56.

Della Porta, Donatella. 2013a. Can Democracy Be Saved? Participation, Deliberation and Social Movements. Cambridge: Polity.

Della Porta, Donatella. 2013b. 'What We Can Do with Visual Analysis in Social Movement Studies: Some (Self) Reflections', in Advances in the Visual Analysis of Social Movements, ed. Nicole Doerr, Alice Mattoni, and Simon Teune 137-44 Bingley: Emerald Group.

Demirhan, Kamil. 2014. 'Social Media Effects on the Gezi Park Movement in Turkey: Politics under Hashtags', in Social Media in Politics: Case Studies on the Political Power of Social Media, ed. B. Pătruț and M. Pătruț 281-314 Cham:Springer International. 
Doerr, Nicole, Alice Mattoni, and Simon Teune. 2013. 'Towards a Visual Analysis of Social Movements, Conflict, and Political Mobilization', in Advances in the Visual Analysis of Social Movements, ed. Nicole Doerr, Alice Mattoni, and Simon Teune, xi-xxvi. Bingley: Emerald Group.

Emre, Ö. Perrin, Bariș Çoban, and Gülüm Şener. 2014. 'Humorous Form of Protest: Disproportionate Use of Intelligence in Gezi Park's Resistance', in New Opportunities and Impasses: Theorizing and Experiencing Politics: Materials of POLITSCI'13: Political science conference, comp. G.E. Zeynep, 430-447. Istanbul: DAKAM Publishing.

Evered, Kyle T. 2018. 'Erasing the Place of Dissent: Inscriptions and Eliminations of Gezi Park Graffiti', AREA: Royal Geographical Society 51(1): 1-11. https://doi. org/10.1111/area.12439.

Farro, Antimo L., and Deniz Günce Demirhisar. 2014. 'The Gezi Park Movement: A Turkish Experience of the Twenty-first-Century Collective Movements', International Review of Sociology 24: 176-189.

Fisher, Kimberly. 1997. 'Locating Frames in the Discursive Universe', Sociological Research Online 2(3): 1-24.

Gambetti, Zeynep. 2014. 'Occupy Gezi as Politics of the Body', in The Making of a Protest Movement in Turkey: \#occupygezi, ed. U. Özkırımlı, 89-102. London: Palgrave Pivot.

Gamson, William A., David Croteau, William Hoynes, and Theodore Sasson. 1992. 'Media Images and the Social Construction of Reality', Annual Review of Sociology 18(1): 373-393.

Gitlin, Todd. 2003. The Whole World Is Watching: Mass Media in the Making and Unmaking of the New Left. Berkeley: University of California Press.

Goffman, Erving. 1974. Frame Analysis: An Essay on the Organization of Experience. Cambridge, MA: Harvard University Press.

Iğsız, Aslı. 2014. 'Neoliberalism, Illegality and the State of Exception in Turkey', in The Making of a Protest Movement in Turkey: \#occupygezi, ed. U. Özkırımlı,121-131 London: Palgrave Pivot.

Jacobs, Jane M. 2002. Edge of Empire: Postcolonialism and the City. London: Routledge. Jost, John T., Pablo Barberá, Richard Bonneau, Melanie Langer, Megan Metzger, Jonathan Nagler, Johanna Sterling, and Joshua A. Tucker. 2018. 'How Social Media Facilitates Political Protest: Information, Motivation, and Social Networks', Political Psychology, 39(S1): 85-118.

Juris, Jeffrey. 2012. 'Reflections on \#Occupy Everywhere: Social Media, Public Space and Emerging Logics of Aggregation', American Ethnologist 39: 259-279.

Karatas, Duygu, and Erkan Saka. 2017. 'Online Political Trolling in the Context of Post-Gezi Social Media in Turkey', International Journal of Digital Television 8: $383-401$. 
Kaun, Anne. 2015. 'Regimes of Time: Media Practices of the Dispossessed', Time \& Society 24: 221-243.

KONDA. 2014. 'Gezi Report: Public Perception of the "Gezi Protests": Who Were the People at Gezi Park?', 5June.http://konda.com.tr/en/raporlar/KONDA_Gezi_Report.pdf. Accessed 31.03.19.

Lebron, Christopher J. 2017. The Making of Black Lives Matter: A Brief History of an Idea. New York: Oxford University Press.

Letsch, Constanze. 2015. 'Gezi Park Protest Trial: Turkish Court Acquits All 26 Defendants', The Guardian, 29 April.

Levy, Helton. 2018. 'Disrupting the Old Periphery: Alternative Media, Inequality and Counter-Mapping in Brazil', Westminster Papers in Communication and Culture 13: 61-76.

Lovink, Geert. 2011. Networks without a Cause: A Critique of Social Media. Cambridge: Polity Press.

Mannheim, Karl. 1952. Ideology and Utopia: An Introduction to the Sociology of Knowledge. London: Routledge and Kegan Paul.

Mattoni, Alice, and Emiliano Treré. 2014. 'Media Practices, Mediation Processes, and Mediatization in the Study of Social Movements', Communication Theory 24: 252-271.

Mercea, Dan, Duygu Karatas, and Marco T. Bastos. 2018. 'Persistent Activist Communication in Occupy Gezi', Sociology 52: 915-933.

Ogan, Christine, and Onur Varol. 2017. 'What Is Gained and What Is Left to Be Done When Content Analysis Is Added to Network Analysis in the Study of a Social Movement: Twitter Use during Gezi Park', Information, Communication \& Society 20(8): 1220-1238.

Ogan, Christine, Roya Imani Giglou, and Leen d'Haenens. 2016. 'The Relationship between Online and Offline Participation in a Social Movement', in Taking the Square: Mediated Dissent and Occupations of Public Space, ed. Maria Rovisco and Jonathan Corpus Ong, 117-138. London: Rowman \& Littlefield.

Olesen, Thomas. 2017. 'Memetic Protest and the Dramatic Diffusion of Alan Kurdi', Media, Culture \& Society 40: 656-672.

Özel, Soli. 2014. 'A Moment of Elation: The Gezi Protests/Resistance and the Fading of the AKP Project', in The Making of a Protest Movement in Turkey: \#occupygezi, 7-24. London: Palgrave Pivot.

Rehmann, Jan. 2013. 'Occupy Wall Street and the Question of Hegemony: A Gramscian Analysis', Socialism and Democracy 27: 1-18.

Schlosberg, David. 2007. Defining Environmental Justice: Theories, Movements, and Nature. Oxford: Oxford University Press.

Schmitter, Philippe. 2011. 'The Future of "Real-Existing” Democracy', Society and Economy 33: 399-428. 
Snow, David A., E. Burke Rochford, Jr, Steven K. Worden, and Robert D. Benford. 1986.

'Frame Alignment Processes, Micromobilization and Movement Participation', American Sociological Review 51: 464-481.

Tarrow, Sidney. 2011. Power in Movement. Cambridge: Cambridge University Press. Tufekci, Zeynep. 2014. 'Social Movements and Governments in the Digital Age: Evaluating a Complex Landscape', Journal of International Affairs 68: 1-18.

Tufekci, Zeynep. 2017. Twitter and Tear Gas: The Power and Fragility of Networked Protest. New Haven: Yale University Press.

Vatikiotis, Pantelis, and Zafer F. Yörük. 2016. 'Gezi Movement and the Networked Public Sphere: A Comparative Analysis in Global Context', Social Media + Society 2: 2056305116662184 .

Zik, M. Ragip. 2018. 'One Building, Several Facades: Political Showcasing in Contemporary Turkey, Open Democracy, 17 October. https://www.opendemocracy.net/ mrag-p-z-k/one-building-several-facades-political-showcasing-in-contemporaryturkey. Accessed 31.03.19.

\section{About the Authors}

Dan Mercea is Senior Lecturer in the Department of Sociology at City, University of London. He is the author of Civic Participation in Contentious Politics: The Digital Foreshadowing of Protest (Palgrave, 2016).

Helton Levy is a journalist, lecturer and Research Associate at University College London. He is author of The Internet, Politics, and Inequality in Contemporary Brazil: Peripheral Media (Rowman \& Littlefield, 2018). 